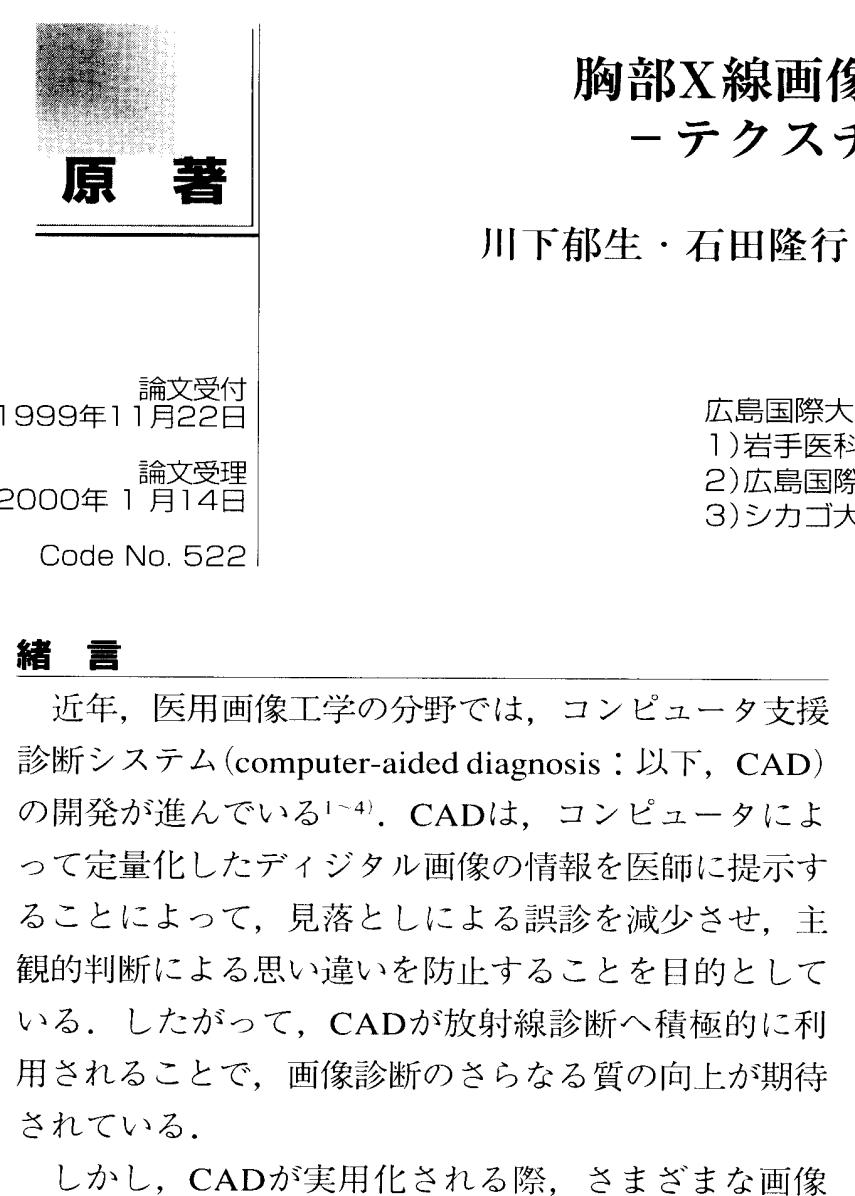

撮像システムの使用や施設間の撮影条件の違いによる 画質の異なる画像に対して, CADの結果に影響を受 けることが想される。特に, 微細で淡い陰影の特徵 を計測している胸部画像の間質性肺疾患検出のCAD は，画質の違いによって大きな影響を受けやすい可能 性がある. 本研究の目的は, 胸部間質性肺疾患検出の CADに执いて使用されているテクスチャ解析占につい て，画質の影響を明らかにすることである。

本研究では, 画質の異なる画像として, 照射線量と 散乱線含有率を変化させて画像を撮影した場合の，テ クスチャ尺度に与える影響についてファントム実験に

\title{
Computer-aided Diagnosis in Chest Radiography: Study of the Effect Caused by Varied Image Quality on Texture Analysis
}

\author{
IKUO KAWASHITA, TAKAYUKI ISHIDA, SHIGEHIKO KATSURAGAWA, ") HIDETAKA ARIMURA, ${ }^{2)}$ \\ and KUNIO DOI') \\ Department of Clinical Radiology. Hiroshima International University \\ 1 ) Department of Radiology, Iwate Medical College \\ 2) Department of Clinical Engineering. Hiroshima International University \\ 3) Kurt Rossmann Laboratories for Radiologic Image Research. Department of Radiology. \\ University of Chicago \\ Received Nov. 22, 1999; Revision accepted Jan. 14, 2000; Code No. 522
}

\section{Summary}

Computer-aided diagnosis (CAD) system has been developing in the field of medical imaging. As CAD becomes more common in diagnostic radiology, it is expected that diagnostic performance will be improved. In actual use, however, the results of CAD might be affected by the quality of images, which are obtained under different exposure conditions and/or with differing devices. In this study, we investigated the effect of varied image quality on the results of texture analysis, a method developed by Katsuragawa, et al. and used in CAD for the detection of interstitial lung disease. To provide samples of varying image quality, we obtained images using various exposure doses and scatterer thicknesses. It was found that texture analysis was affected by differences in scatterer thickness.

47fy words: Computer-aided diagnosis, Texture analysis, Interstitial lung disease, Exposure, Scatter 
より検討した。

\section{1. 方法}

\section{1-1 使用機器およびファントム}

本実験では，X線発生装置としてインバータ式X線 高電圧装置UD150B-3 (株式会社島津製作所製)を使用 し，画像読取装置はFCR9000(富士メディカルシステ ム株式会社製)を用いた。立位ブッキースタンドはBR1 (株式会社島津製作所製)でグリッド密度が34 lines/ $\mathrm{cm}$, グリッド比が 8：1のグリッド(SOYEE社製)を使 用した。被写体は, 胸部ファントムPBU(株式会社京 都科学製)を用い, 散乱体としてアクリルファントム XAC型 (株式会社京都科学製)を使用した。この胸部フ アントムには摸擬血管が入っており，この画像の肺野 テクスチャの周波数成分は，実際の臨床胸部X線画像 の血管影に相当する周波数成分が含まれていることを 確認している.さらに, 異常陰影として, きめの粗い 海綿スポンジに，二スを染み込ませたあと乾燥させた 間質性浸潤影の摸擬ファントムを作成し，これを胸部 ファントムに重ねて用いた。Fig.1に右下肺外側に摸 擬間質性浸潤影を付加したファントムの画像を示す。

使用したファントムの妥当性については，考察の冒頭 に記述する．また，テクスチャ解析で使用したコンピ ュータはFMV6233T7(富士通株式会社製)，OSは Linuxである.

本論文では，摸擬間質性浸潤影を含まない胸部人体 ファントムの画像を“正常画像”之呼び，摸擬間質性浸潤 影を含んだ画像を“異常画像”と呼ぶことにし，両者の 画像から計算した肺野のテクスチャ尺度を比較した。

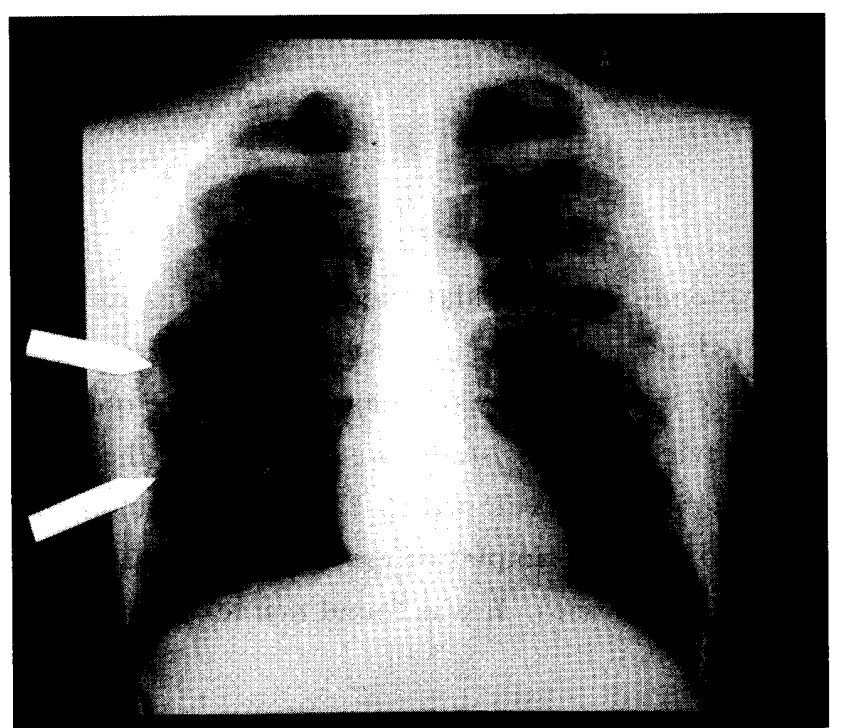

Fig. 1 Chest phantom with interstitial lung disease.

\section{1-2 テクスチャ解析}

本研究で使用したテクスチャ解析は, 間質性浸潤影 の特徵量を, 画像の関心領域(region of interest: ROI)の パワースペクトルから計算した二つの物理的な尺度に よって定量的に評価し，病変を検出するものである ${ }^{5}$. 間質性肺疾患とは，肺胞間などの間質に異物の集積や 異常な浸潤を来す疾患で，その原因には肺癌や結核な どさまざまな要因が含まれている。この間質性浸潤影 はコントラストが極めて低くパターンが複雑で, 粒状 陰影, 網目状陰影, 網粒状㓌影など主観的にしか定義 されていないこともあり，診断は放射線画像診断の中 では困難な問題の一つといわれている.

テクスチャ解析では, 以下の式で示すように, 間質 性肺浸潤影を, 肺野テクスチャの濃度変動の大きさを 表現する $\mathrm{rms}$ 変動值 (以下, $\mathrm{rms}$ 值) $R$ と陰影の粗さ (ま たは紐かさ)を表現するパワースペタトルの一次モー メントMの二つの尺度によって検出する。

$$
\begin{aligned}
& R=\sqrt{\int_{-\infty}^{\infty} \int_{-\infty}^{\infty} V^{2}(u, v)|F(u, v)|^{2} d u d v} \\
& M=\frac{\int_{-\infty}^{\infty} \int_{-\infty}^{\infty} \sqrt{u^{2}+v^{2}} V^{2}(u, v)|F(u, v)|^{2} d u d v}{\int_{-\infty}^{\infty} \int_{-\infty}^{\infty} V^{2}(u, v)|F(u, v)|^{2} d u d v}
\end{aligned}
$$

ここで, $V(u, v)$ および $F(u, v)$ は，それぞれ眼のレス ポンス関数および肺野テクスチャのフーリ工変換であ る.テクスチャ解析の手法の概要をFig.2に示す.

まず，解析の対象となるディジタル画像の肺野領域 を自動的に同定し，マトリクスサイズ $32 \times 32$ $(6.4 \mathrm{~mm} \times 6.4 \mathrm{~mm})$ の関心領域を肺野の末梢にできるだ

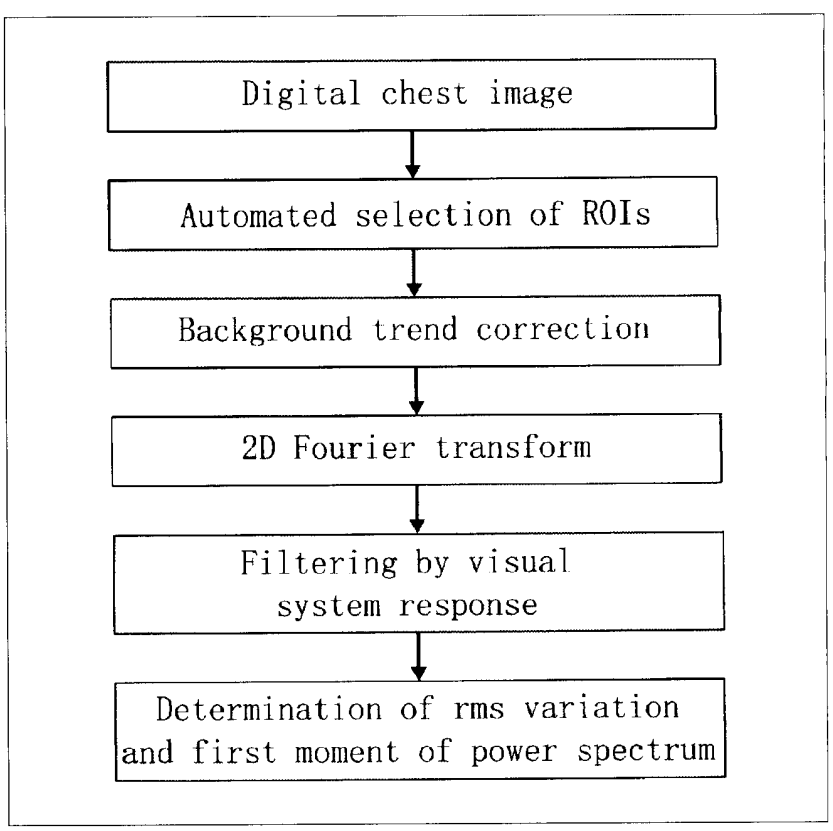

Fig. 2 Overall schema of texture analysis. 
け多く設定する。このうち，胁骨のエッジを含んだ ROIを, エッジの方向のヒストグラム分析を用いて除 外する7!. 次に，残されたROIに対して，二次元面関 数を用いたバックグラウンド補正 ${ }^{5)}$ を行い, 肺や胸壁 の構造による大まかな濃度变動を取り除く。これによ り肺野の微細なテクスチャの変動成分だけを抽出す る.さらに，バックグラウンド補正されたROIの二次 元フーリエ変換から求められるパワースペクトルを, 眼のレスポンス関数りを用いてフィルタリングする。 眼のレスポンス関数は, 高周波の画像のノイズ成分と 低周波の残留バックグラウンド成分を抑制する。テク スチャ解析により得られた二つの尺度は, 正常肺のデ 一タベースから得られた二つの尺度の平均值と標準偏 差によって正規化される，最後は，それぞれの胸部画 像に扮ける全ROI数に対する異常ROI数の割合を求 め, その割合が閾值よりも大きい場合は異常, 小さい 場合は正常とする判断基準を用いて正常肺と異常肺の 判別を行う6).

本研究では, rms值とパワースペクトルの一次モー メントの二つのテクスチャ尺度を求め，この二つの尺 度の変化量から, 照射線量および散乱線含有率のテク スチヤ解析に及ぼす影響を分析した。

\section{1-3 画像の撮影}

撮影条件は，距離 $200 \mathrm{~cm}$, 照射野サイズ $40 \times 40 \mathrm{~cm}^{2}$, 管電圧 $120 \mathrm{kV}$ ，管電流 $100 \mathrm{mAで}$ 行った。また，画像読 取条件はラチチュード固定 (L值2.2)で，システム感度 は自動調整のセミオートモードを使用した。

画質の異なる画像を得るために，照射線量，また は，散乱線含有率を変化させた条件で胸部ファントム を撮影した，な掞，照射線量，散乱線含有率を変化さ せた範囲は，画質の違いによる影響を調べることを目 的としているため，臨床の現場で考えられる最大限の 範囲で条件を設定した。

\section{1-3-1 照射線量の異なる画像の撮影}

コンピューテッドラジオグラフィ (computed radiography：以下，CR）は，自動階調処理により，照 射線量が变化しても画像の濃度やコントラストが一定 に保たれるように工夫がされている，そのため，施設 ごとに違った線量で撮影を行っている場合も多い。そ して, 照射線量の違いはX線量子モトルに影響を与 え，画像の粒状特性を変化させる。そこで，次に示し たような条件で撮影を行った。

本実験で使用したCRは， $80 \mathrm{kV}, 2.58 \times 10^{-7} \mathrm{C} / \mathrm{kg}$ の条 件で一様なX線露光を行い, 得られた画像のフィルム の写真濃度が1.2になるシステムの感度を基準として いる．この時の感度を 1.0 と考えて，この感度が $0.5 一$ 2.0 になる範囲(照射線量ではそれぞれ $2.22 \times 10^{-6}$ 一 $\left.8.74 \times 10^{-6} \mathrm{C} / \mathrm{kg}\right)$ となるように撮影時間を 6 段階に変化 させて $(22,36,45,63 ， 71,90 \mathrm{msec})$ 撮影を行い, 得られた各画像のテクスチャの尺度を比較した。

\section{1-3-2 散乱線含有率の異なる画像の撮影}

散乱線含有率は, 散乱体の種類と体積, 散乱体と 検出器の位置関係，照射野の大きさ等により変化す る. 本研究では, 患者の体格差に起因する散乱線含有 率の違いを想定し，散乱体厚を 0 〜 $20 \mathrm{~cm}$ まで 6 種類 に $(0,4,8,12,16,20 \mathrm{~cm})$ 変化させて画像を撮影し た。Fig.3に散乱体を付加した時の実験配置図を示 す。この時，イメージングプレートに到達する照射線 量が一定になるように撮影時間を設定した（110， 160，280，500msec，1.2，2.5 sec)。 その他の撮影条 件は，照射線量の異なる画像を撮影した時と同じであ る。なお、アクリル板の厚さを変化させた時のアクリ ル板のみの散乱線含有率を鉛ディスク法で求めたとこ ろ, 各アクリル板厚に対して，それぞれ28.4，37.4， 46.2，54.6，61.1\%であった。

\section{2. 結 果}

\section{2-1 1 照射線量依存性}

照射線量を変化させた時のrms值の変化をFig.4に示 す．実線㧍よび点線は，それぞれ，正常画像と異常画 像から計算したrms值を示す。このグラフから，照射 線量が少ない場合，rms值は高い值を示していること が分かる．また，正常画像では異常画像より $\mathrm{rms}$ 值は 低い值を示し, 正常画像と異常画像のrms值の変化の 傾向はほほ等しくなった，また，照射線量を変化させ た時の，パワースペクトルの一次モーメントの変化 を, Fig.5に示す．照射線量を減少させるにつれて， 一次モーメントも高い值を示した。また，正常画像で は異常画像より一次モーメントは高い值を示し，正常 画像と異常画像の一次モーメントの変化の傾向はほほ 等しくなった.

\section{2-2 散乱線含有率依存性}

散乱線含有率を変化させた時のrms值の変化を,

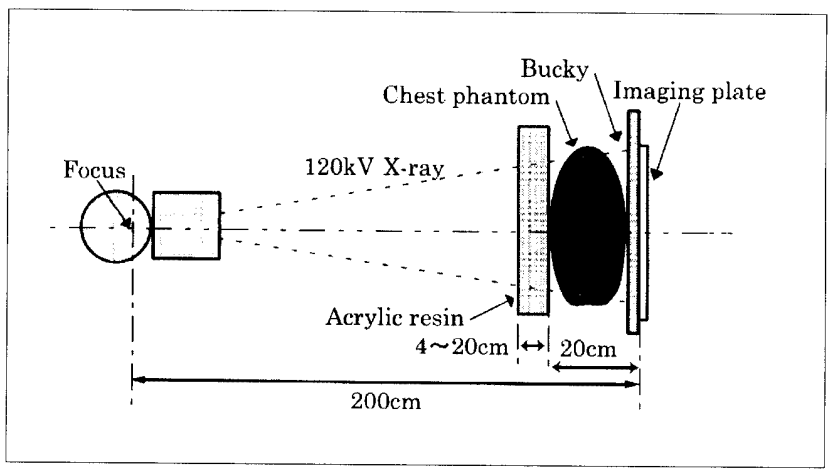

Fig. 3 Geometry of acrylic resin. 


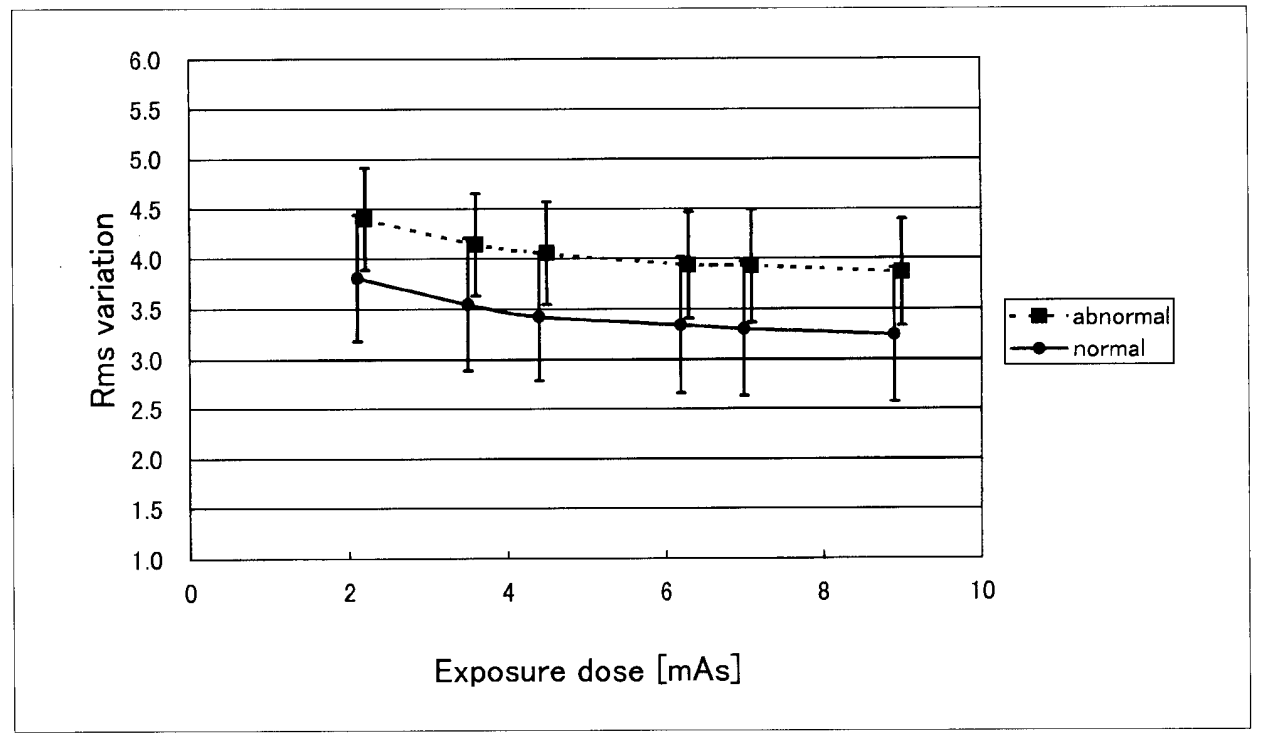

Fig. 4 Relationship between average rms variation and exposure.

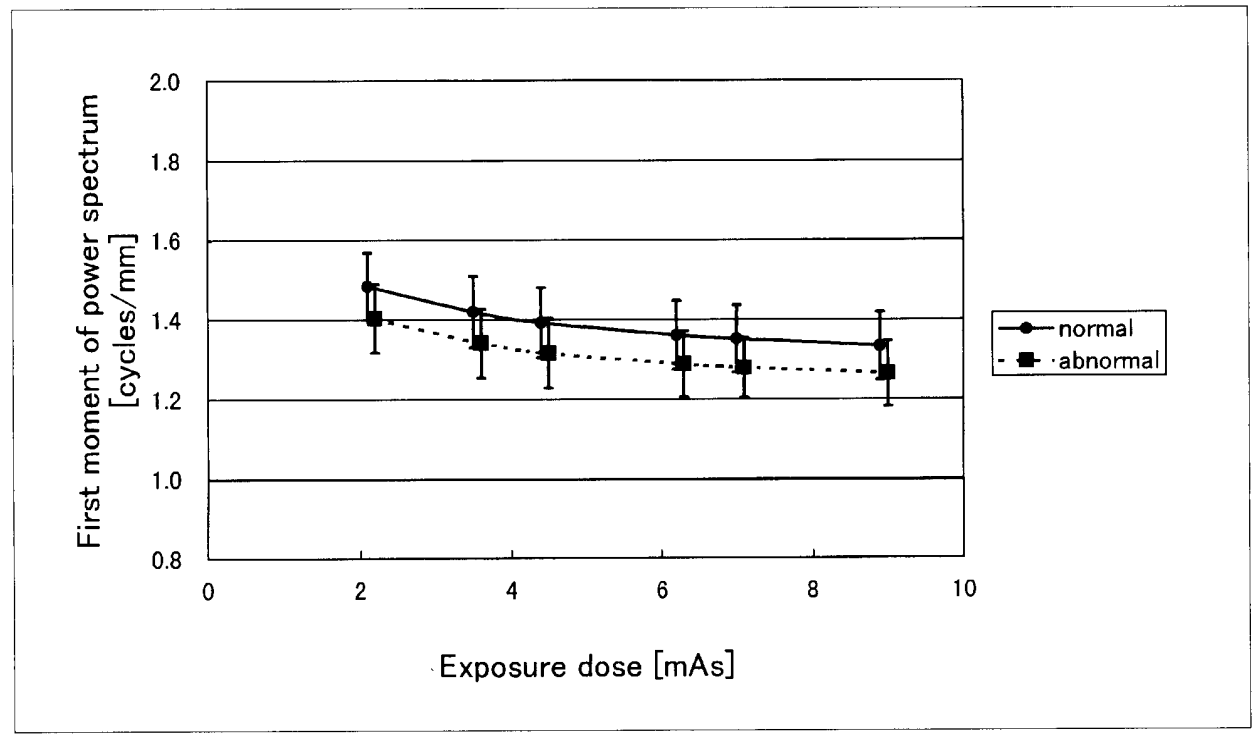

Fig. 5 Relationship between average first moment of power spectrum and exposure.

Fig.6に示す．散乱線含有率が増加するほどrms值は減 少した。また，散乱線含有率を変化させた際のパワー スペクトルの一次モーメントの変化を,Fig.7に示 す。散乱線含有率が増加するほど，パワースペクトル の一次モーメントは高い值となった。散乱線含有率を 変化させた場合と, 照射線量を変化させた場合の, $\mathrm{rms}$ 值抢よびパワースペクトルの一次モーメントの変 動量を比較すると, 両者ともに, 散乱線含有率を変化 させた場合の方が，変動量が大きいことが分かった。

\section{3. 考}

この研究で使用した胸部ファントム，挍よび間質性 肺浸潤影の模擬ファントムが，実際の症例の摸擬ファ ントムとして使用可能であることを確認するために， 二つのテクスチャ尺度の值を比較した。 その結果，粒
状㓌影のある実際の症例では, rms値とパワースペク トルの一次モーメントの平均值はそれぞれ 4.37 , 1.43cycles/mmであった，実際の正常症例の場合，そ れぞれ3.56，1.51 cycles/mmであった。一方，ファン トムの異常画像では, $\mathrm{rms}$ 值とパワースペクトルの一 次モーメントの平均值はそれぞれ4.05, 1.31 cycles/ $\mathrm{mm}$, 正常画像では, それぞれ3.42, $1.39 \mathrm{cycles} / \mathrm{mm}$ あった。以上の結果より，ファントムの画像のrms值 および一次モーメントが，実際の症例の值よりやや低 いものの，近い值を持っていることから，本研究にお いて，これらのファントムが実際の症例の摸擬ファン トムとして，使用可能であると判断した.

照射線量の減少に伴う rms值，およびパワースペクト ルの一次モーメントの増加の原因は, X線量子モトル の増加に起因すると考えられる。つまり，入射X線光 


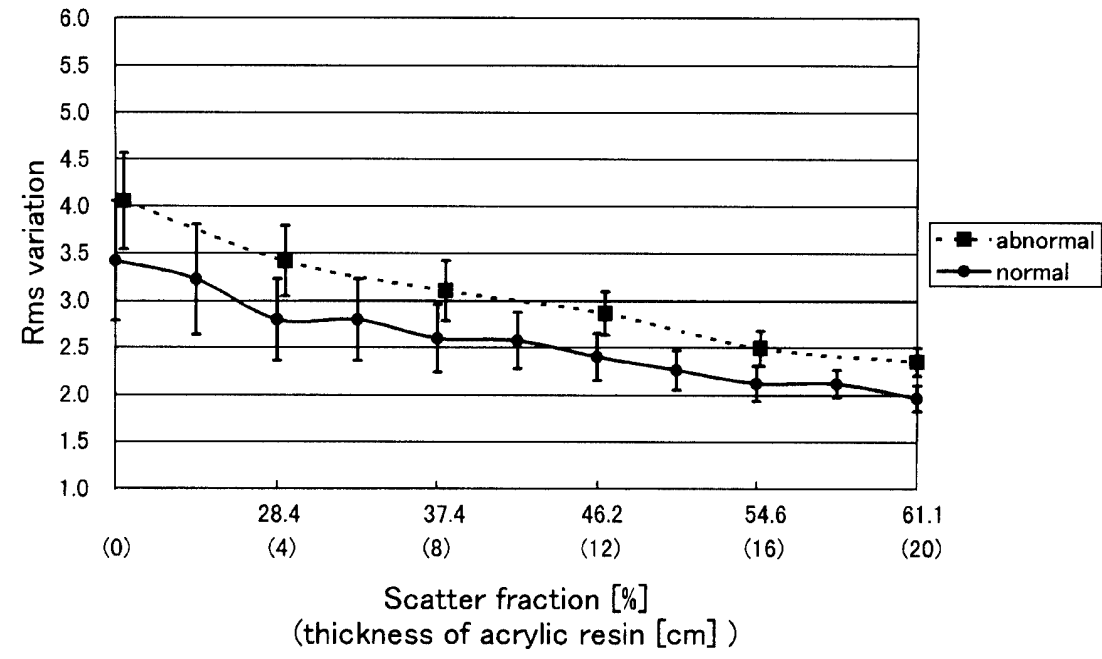

Fig. 6 Relationship between average rms variation and scatter fraction (thickness of acrylic resin).

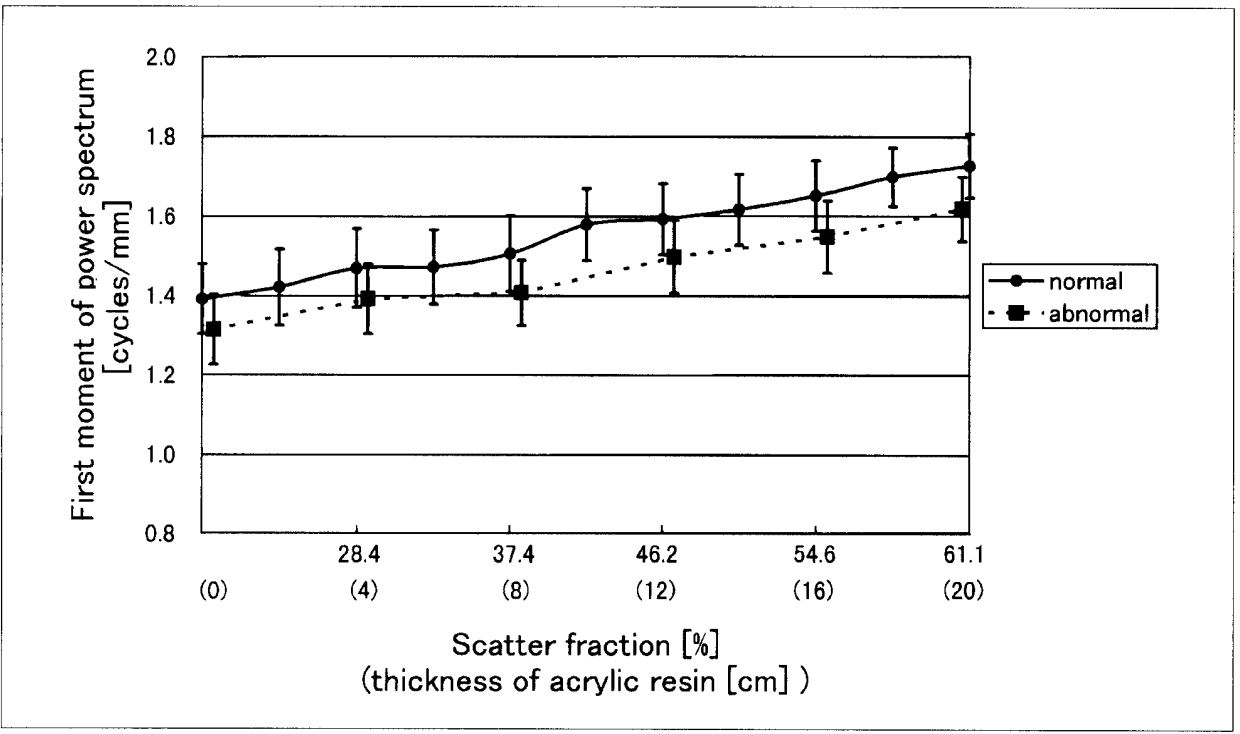

Fig. 7 Relationship between average first moment of power spectrum and scatter fraction (thickness of acrylic resin).

子数の減少によりX線分布の不均一性が増加したた め，画像の粒状性を低下させ，その結果，濃度変動が 大きくなり rms值は増加したと考えられる。一方，パワ 一スペクトルの一次モーメントは，空間周波数成分の 平均值を意味するが，照射線量を減らした場合，肺野 を構成する周波数成分は变化しないで，X線量子モ卜 ルが増加したことになる。したがって，一次モーメン トの值がわずかに増加した原因はX線量子モトルの高 い周波数成分が相対的に増加したためと考えられる.

散乱線含有率の増加に伴う rms值減少の原因は, 散 乱線の増加により，画像のコントラストが低下したこ とによると考えられる。

次に，パワースペクトルの一次モーメントの増加に ついて考察する。一般に散乱線含有率が増加すると，
被写体のコントラストが低下することによって，対応 する周波数領域のパワースペクトルは低下する。ま た，本実験では，イメージングプレートに到達する照 射線量が一定になるように撮影しているため，X線の 量子雑音に対応寸るパワースペクトルは，ほぼ一定に 保たれていると考えられる。したがって，散乱線含有 率が増加すると，量子雑音に対応するパワースペクト ルの寄与が相対的に大きくなり，一次モーメントの値 は増加したものと推測される。しかし，実際の臨床で は, 患者体厚の増加に伴い, 対象㓌影とイメージング プレート間の距離が変化する場合もあるため, 幾何学 的不鋭など他の影響も考えられる，そのため，実際の 臨床での散乱線含有率とパワースペクトルの一次モー メントの関係を明らかにするには，さらに検討が必要 
であろう。

また，テクスチャ尺度の散乱線含有率依存性を調心 る実験では, rms值やパワースペクトルの一次モーメ ントを計算する時，ピクセル值から直接計算した場合 と, $\mathrm{CR}$ ステムの入出力変換特性の曲線を利用して ピクセル值から相対X線強度に変換した場合について 計算を行ったそその結果，両者で得た結果は同じ傾向 を示した。その理由は，CRシステムの入出力特性が 直線的であることに関係していると考えられる.

本研究により照射線量および散乱線含有率の違いが テクスチャ解析に及ぼす影響が明らかとなった。そこ で，照射線量または散乱線含有率の值が，何らかの方 法で測定できれば，照射線量または散乱線含有率の違 いによるテクスチャ尺度の変動の補正が可能であると 考えられる. シカゴ大学で開発されているテクスチャ 解析で，ルールベース法で正常肺-異常肺の分類を行

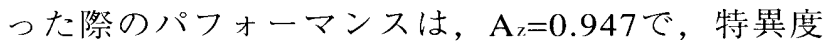
(specificity)が0.900の時の感度(sensitivity)は, $0.874^{8)}$ と高い值を示している。したがって，この補正を行う ことができれば，さらにパフォーマンスが向上するこ
とが期待される。

\section{4. 結 語}

照射線量と散乱線含有率を変化させて画像を撮影 し，テクスチャ尺度に及ぼす影響を調べた。その結 果，照射線量や散乱線含有率が異なれば，rms值やパ ワースペクトルの一次モーメントなどのテクスチャ尺 度に影響することが確認された。特に，散乱線含有率 の違いによる影響が大きいことが分かった。したがっ て, テクスチャ解析を行う際, 散乱線含有率の違いに よる画質の変化が, 解析結果に影響を与える重要な因 子の一つであるといえる。

\section{謝 辞}

稿を終えるにあたり，臨床画像データを提供してい ただきました産業医科大学の中村克巳先生, ならびに 間質性肺浸潤影摸擬ファントム作成において，ご指導 いただきました京都医療技術短期大学の杜下淳次先生 に深く感謝いたします。

本論文の要旨は, 第55回総会学術大会で発表した.

\section{参考文献}

1) Nishikawa RM, Giger ML, Doi K, et al.: Computer-aided detection of clustered microclacifications on digital mammograms. Medical and Biological Engineering and Computing, 33(2), 174-178, (1995).

2) Yin FF, Giger ML, Doi K, et al.: Computerized detection of masses in digital mammograms: Investigation of feature-analysis techniques. J Digital Imaging, 7 (1), 18-26, (1994).

3) Ishida T, Katsuragawa S, Nakamura K, et al.: Iterative image warping technique for temporal subtraction of sequential chest radiographs to detect interval change. Med Phys, 26 (7), 1320-1329, (1999).

4) Giger ML, Bae KT, and MacMahon H: Computerized detection of pulmonary nodules in CT images. Invest Radiol, 29 (4), 459-465, (1994).

5) Katsuragawa S, Doi K, and MacMahon $\mathrm{H}$ : Image feature analysis and computer-aided diagnosis in digital radiography: Detection and characterization of interstitial lung disease in digital chest radiographs. Med Phys, 15 (3), 311-319, (1988).
6) Katsuragawa S, Doi K, and MacMahon H: Image feature analysis and computer-aided diagnosis in digital radiography: Classification of normal and abnormal lungs with interstitial disease in chest images. Med Phys, 16 (1), 38-44, (1989).

7) Chen X, Doi K, Katsuragawa S, et al.: Automated selection of regions of interest for quantitative analysis of lung texture in digital chest radiographs. Med Phys, 20 (4), 975-982, (1993).

8) Katsuragawa S, Doi K, MacMahon H, et al.: Classification of normal and abnormal lungs with interstitial diseases by rulebased method and artificial neural networks. J Digital Imaging, 10(3), 108-114, (1997).

Fig. 1 間質性漫潤影の模擬ファントムを付加した胸部ファントムのX線画像.

Fig. 2 テクスチャ解析の概要.

Fig. 3 アクリルファントムの幾何学的配置.

Fig. 4 rms值の照射線量依存性.

Fig. 5 パワースペクトルの一次モーメントの照射線量依存性.

Fig. 6 rms值の散乱線含有率(アクリル厚)依存性.

Fig. 7 パワースペクトルの一次モーメントの散乱線含有率(アクリル厚)依存性. 